\title{
Relationship between Background Characteristics and Residential Satisfaction of Young Households in Unplanned Neighbourhoods in Kano, Nigeria
}

\author{
Ado $\mathrm{Abdu}^{1,2^{*}}$, Ahmad Hariza Hashim ${ }^{2}$, Asnarulkhadi Abu Samah ${ }^{3}$, \\ Azizah Salim Syed Salim ${ }^{4}$ \\ Department of Geography, Faculty of Earth and Environmental Science, Kano University of Science and \\ Technology, Wudil, Kano, Nigeria \\ Department of Resources Management and Consumer Studies, Faculty of Human Ecology, Universiti Putra \\ Malaysia, 43400 UPM Serdang, Selangor, Malaysia \\ Department of Social and Development Science, Faculty of Human Ecology, Universiti Putra Malaysia Faculty \\ of Human Ecology, Universiti Putra Malaysia, 43400 UPM Serdang, Selangor, Malaysia \\ Department of Architecture, Faculty of Environmental Design, Universiti Putra Malaysia, Faculty of Human \\ Ecology, Universiti Putra Malaysia, 43400 UPM Serdang, Selangor, Malaysia
}

\begin{abstract}
This study examined the relationship between background characteristics and residential satisfaction of young households in unplanned neighbourhoods in Kano, Nigeria. Data was collected from 364 respondents using self-administered questionnaire from three unplanned neighbourhoods. Pearson's correlation analysis revealed age, household income, household size, total number of bedrooms and total number of rooms had positive significant relationship with residential satisfaction of young households in unplanned neighbourhood in the study area. However, there was no significant relationship between length of residence and residential satisfaction of the young households. Analysis of variance (ANOVA) showed that residential satisfaction differed between tenure status and house type of the respondent, while residential satisfaction did not differ between levels of education. Independent t-test revealed that there was no significant difference between employment status and residential satisfaction of the respondents. These relationships indicate that those who are older, higher income and bigger household size, with more room are more satisfied. It is recommended that policy makers and planning authorities should give more emphasis on the improvement of housing situations of young households and their income to enhance their residential satisfaction.
\end{abstract}

Keywords: Background characteristic, residential satisfaction, housing, unplanned neighbourhoods, Young households

\section{Introduction}

Housing is so significant that its impacts on the wellbeing of individuals are regardless of their socioeconomic status, race or belief [1]. It comprises immediate settings, sanitation, drainage, recreational facilities and other economic and social undertakings that improve quality of life [2]. Housing is one of the basic human needs that has impact on the welfare, health and productivity of individuals and households and a priority for the achievement of living standard [2], [1]. Achievement of a house depends not only on how effectively the building provides the setting for activities of daily living but also on the perceptions of its residents [3]. Assessment of residents' perceptions about their housing environment is not limited to the general assumptions of measuring physical and structural adequacy of a house [4]. Residential satisfaction is a measure of households' perceptions and responses about the situations of their residential environment [5]. Thus, insight into the factors that relate to household's residential satisfaction would be framework for future housing policies for improvement of their quality of life [6], [7].

The concept of residential satisfaction has many definitions and applications depending on the context it occurs. The concept has been studied in several fields related to housing studies and it studies date back to the 1940 [8]. Household's satisfaction with residential environment determines their quality of life and an achievement of their needs and aspirations [9]. Residential satisfaction is seen as the difference between actual and desired housing conditions [10], [11]. It is also viewed as an appraisal of conditions of residential environment by individuals with regards to their personal needs, anticipation and achievements [12]. Satisfaction with the residential conditions indicates absence of complaints with the conditions and is sign of congruence between the actual and desired housing situations, while dissatisfaction indicates presence of complaints and degree of incongruence between actual and desired residential situations [13]. According to [14] 
residential environment can be assessed using three approaches distinguished by [15]. The first is purposive approach that viewed satisfaction as a measure of the extent to which the environment enables or constrains the resident's goals. The second is aspiration-gap approach which sees satisfaction as a measure of the gap between dwellers actual and aspired needs. This approach associated with resident's perceptions of residential and or environmental quality [14]. [16] argued that this approach concerns with residents views on residential quality as against experts/technical evaluations and can used for town-planning purposes. The third approach is related to attitude with cognitive, affective and conative components [17], [16], [15] \& [14]. According to [14] conative component (behavioural intentions) is common used in studies related to intention to move [18], [19].

Residential satisfaction has been theorised as an active process in housing adjustment of residential mobility model developed by [20], [21]. They forwarded the idea of "housing deficit' and posited that households assess their housing conditions in relation to family norm and societal norm which are likely to be incongruent. Thus, incongruence between the actual housing conditions of the family and housing norms in the society results to a housing deficit. This housing deficit leads to housing dissatisfaction which results in housing adjustment by the households. The households can adjust housing by reviewing their housing aspirations, by making in-situ adjustment through housing modifications and finally adjust by residential mobility [22]. Studies have shown that there is link between residential satisfaction and socioeconomic and demographic characteristics of the households [13], [23], [24], [25], [14] \& [8].

The importance of socio-economic factors in predicting residential satisfaction of households has been stressed in many studies. For example, a study by [26] found that tenure status of migrants living in unplanned neighbourhood (slum) in Nairobi, Kenya was related to residential satisfaction at all ages. [23] found in their study on housing satisfaction related to health and importance of services in urban Slums: Evidence from Dhaka, Bangladesh found that high income, high age, a smaller family, high education, being female and being an owner of a dwelling are related to housing satisfaction among his rural and urban residents. In contrast, [25] studied residential satisfaction of residents of three cities in China and their findings showed that some socioeconomic and demographic characteristics of the respondents were not related to residential satisfaction except income because majority of them engaged on economic activities. In Nigeria, [8] studies on the influences of socio-cultural experiences on residents' satisfaction in Ikorodu low-cost housing estate, Lagos and the findings show that there is significant difference in level of satisfaction of the residents in the housing elements such as gender, ethnicity, family size, family structure, religious beliefs, ethnic group of residents, social relation, years of living in area and age of residents, while no significant difference was found between residents' level of satisfaction and household position and marital status. Therefore, these studies revealed complex relationship between residential satisfaction and socioeconomic and demographic characteristics of the residents.

Previous studies on residential satisfaction focused on the perceptions of residents of well-planned public and private housing developments in both developed and developing countries. However, there are few studies on residents of unplanned (informal) neighbourhoods. The existing studies focused on households of all age groups however, little is known on young households with children and specifically few studies focused on the relationship between socioeconomic and demographic factors and level of residential satisfaction of young households with children in unplanned neighbourhoods. Housing and neigbourhoods' needs of young households with children differ from childless young couples and older couples with shrinking households because of household size [27], especially those in unplanned neighbourhoods. This is because unplanned neighbourhoods are seen by authorities as residential areas developed without compliance to building laws and planning regulations as against planned areas where there is compliance and lack adequate facilities and services for decent living. [28], argued that provision of services and facilities in major cities in developing countries like Nigeria is uneven. Significant proportion (over 70\%) of urban dwellers in the country lives in these neighbourhoods [29], [30].

Based on these arguments, this study aimed to examine the relationship between background characteristics (age, household income, household size, level of education, tenure status, employment sector, total number of bedroom, total number of rooms and length of stay) and residential satisfaction of young households in three unplanned neighbourhoods in Kano, Nigeria. Therefore, the study examines the relationship between background characteristics and residential satisfaction of young households in three unplanned neighbourhoods in Kano, Nigeria. 


\subsection{Background of the study Area}

\section{Methodology}

Kano metropolis is one of the largest cities in Nigeria and a capital city of Kano State. It is located between latitude $11^{\circ} 55^{\prime} 23.93^{\prime \prime} \mathrm{N}$ to $12^{\circ} 3^{\prime} 53.10^{\prime \prime} \mathrm{N}$ and longitude $8^{\circ} 27^{\prime} 42.26^{\prime \prime} \mathrm{E}$ to $8^{\circ} 36^{\prime} 41.62^{\prime \prime} \mathrm{E}$ and is 1549 feet above sea level [31]. The metropolis comprises eight out of forty-four Local Governments Councils in Kano State and it is the largest commercial and industrial centre in Northern Nigerian and the second in the whole Nigeria [32]. Kano has been experiencing higher population growth and rapid urbanization, since independence in 1960 [33], [31] \& [1]. For instance, in 1932, the population of Kano was 83,000, by 1952, it increased to 127,000, in 1963 it had increased 295,432, in 1973 it was 760,000, in 1991 the figure increased to 1.6 million and 2.84 million in 2006 census and currently the rate of growth rate was estimated at 5.5\% per annum [32], [31]. The growth has manifested in the high proportion of young households in Kano city. According to a report by [34], Kano had 772, 850 young households who aged between 25 and 44 years accounting for $6.15 \%$ of the national figure. This current population growth of Kano metropolis leads to increase in the demands for urban facilities and services including housing which are currently quantitative and qualitatively inadequate [1]. This situation results in the emergence of slums and unplanned residential areas within the metropolis which are growing faster than the planned residential areas [31], [1]. [35], claimed that over two - third of the built-up areas within the metropolitan Kano were unplanned. The houses in these unplanned areas are self-built including traditional compound houses, single family attached houses, two storey houses and Bungalow houses. The study areas are randomly selected from peripheral unplanned neighbourhoods and are located at different sections of Kano metropolis; Dorayi is located at western, Wailari at the southern, while Gama E is located at the eastern part and the neighbourhoods are medium density areas (Fig. 1).

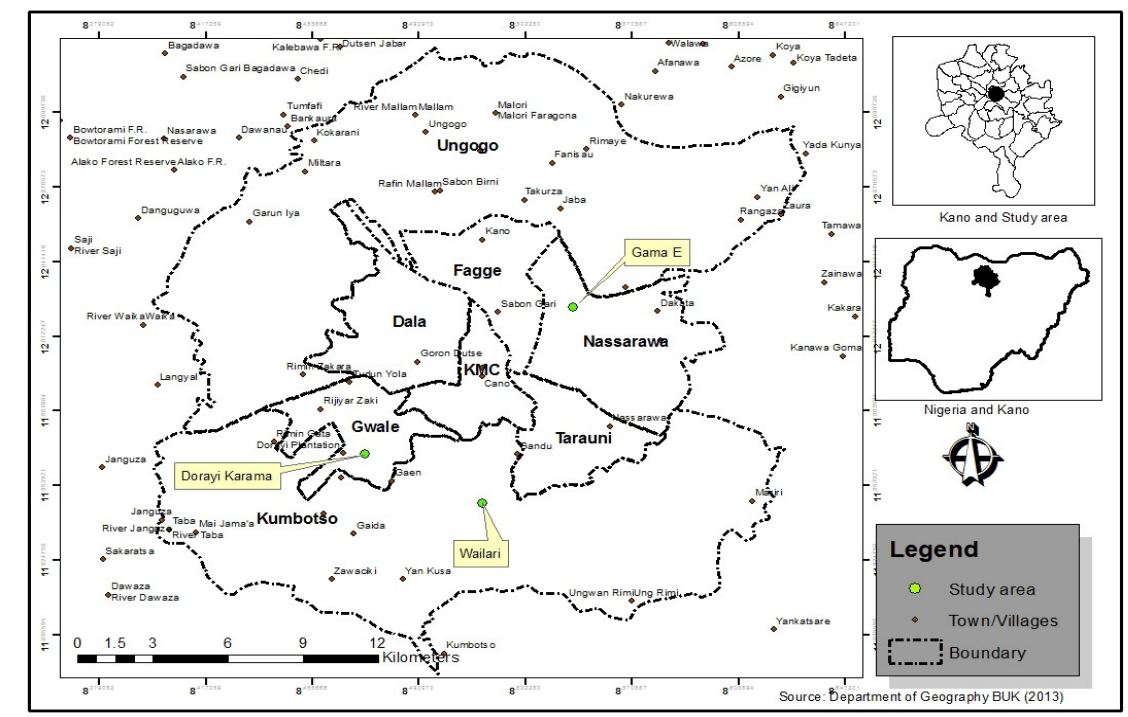

Source: Department of Geography, Bayero University Kano, Nigeria (2013)

Fig. 1: Map of Kano showing the Study area

\subsection{Sampling and Data analyses procedures}

The data for this study was obtained through a questionnaire survey of three randomly selected unplanned neighbourhoods in Kano, Nigeria. The neighbourhoods were Wailari, Dorayi and Gama E and the survey was conducted between $24^{\text {th }}$ November, 2013 and $5^{\text {th }}$ February, 2014 on the heads of young households in the unplanned neighbourhoods. Sample size of 368 of the respondents out of population of 9,164 young households was determined using [36] criteria at the unplanned neighbourhoods in the city. According to the criterion, the determine sample size is 368 at $\alpha=.05$ level of significance ( $95 \%$ confident interval). Of the total sample, there were 78, 136 and 154 respondents in Wailari, Dorayi and Gama E, respectively (figure 1). The respondents were selected using probability proportionate to sample procedure from the three neighbourhoods and systematic random sampling techniques was employed to select every fifth household for data collection, until the required numbers for each of the three neighbourhoods were reached. Multi-stage cluster sampling technique was employed for selecting the sample size from the neighbourhoods. Selected neighbourhoods were Gama E from Nassarawa Local Government council, located at the eastern part of Kano metropolis, Dorayi from Gwale Local Government council, located at western part and Wailari selected from Kumbotso local government council, at the southern part see fig. 2 (showing the maps for these three locations selected). A structured questionnaire was 
employed as an instrument for data collection and a set of the questionnaire was administered to the sample of 368 respondents in which 364 were successfully retrieved and used in the analysis, while 4 were invalid. The questionnaire had several sections. The first section was on Background characteristics namely; receipt Age, household size, household income, level of education, tenure status, types of house, and total numbers of bedrooms, total number of rooms and length of stay. The instrument used to measure residential satisfaction was adopted from the available literature. The second section encompasses questions on the level of satisfaction with housing and neighbourhood were measured on five-points Likert scale options from " 1 " for very dissatisfied to "5" for dissatisfied. The respondents were "how satisfied are with their current housing" and also asked "how satisfied are they with their current neighbourhood". Housing satisfaction and neighbourhoods satisfaction were summed up and their mean was obtained by dividing sum with 2 to get overall residential satisfaction of the households. [37], argues that residential satisfaction encompasses housing satisfaction and neighbourhood satisfaction.

The analysis of the data involved descriptive statistics which was employed to analyse the overall residential satisfaction of the respondents. Pearson's product moment correlation was used to determine the relationship age, household size, household income and length of residence. [38], shows that Pearson's product moment correlation can be used to measure the strength and direction of relationship between continuous independent variable and continuous dependent variable. Analysis of variance (ANOVA) was also employed and Independent t-test were used to determine differences between categorical background variables and residential satisfaction. Independent t-test is used to determine the mean differences of a continuous variable and one independent variable with two categories, while ANOVA is used to determine the mean differences between one continuous variable with three or more categories [39], [38].

\section{Results and Discussion}

\subsection{Results}

\subsubsection{Residential satisfaction}

The results of the description of the two questions measuring residential satisfaction are shown in table 2, for the current neighbourhoods. The finding revealed that mean for housing satisfaction $(\mathrm{M}=3.53, \mathrm{n}=364, \mathrm{SD}=$ $0.864)$, neighbourhood satisfaction $(M=3.76, \mathrm{n}=364, \mathrm{SD}=0.581)$ and residential satisfaction $(\mathrm{M}=3.65, \mathrm{n}=$ 364 , $\mathrm{SD}=0.723)$. The result revealed that mean for neighbourhood satisfaction was high than housing satisfaction while the mean for the residential satisfaction scale was the average of the housing and neighbourhood satisfaction means.

Table 1: Residential satisfaction

\begin{tabular}{|c|c|c|c|}
\hline Variables & Mean & SD & Range \\
\hline Housing Satisfaction & 3.53 & 0.864 & $1-5$ \\
\hline Neighbourhood Satisfaction & 3.76 & 0.581 & $2-5$ \\
\hline $\begin{array}{l}\text { Overall Residential Satisfaction(two items } \\
\text { combined) }\end{array}$ & 3.645 & 0.7225 & $2-5$ \\
\hline
\end{tabular}

\subsection{2: Relationship Between Background Characteristics and Overall Residential satisfaction}

The analysis in table 2 below shows the results of relationship between background characteristics and overall residential satisfaction using Pearson's product moment correlation analysis, analysis of variance (ANOVA) and independent t-tests. The findings revealed that, there was significant positive and low relationship between age $(\mathrm{r}=.209, p=.000)$, household monthly income $(\mathrm{r}=.280, p=.000)$ and household size and residential satisfaction of the respondents $(\mathrm{r}=.163, p=.000)$.this was indicating that those who are older, with higher income and large household size had higher residential satisfaction. However, the analysis shows that there was no significant relationship between length of stay and residential satisfaction $(\mathrm{r}=-.023, \mathrm{~N}=364$, $p=0.451)$, indicating that year of residence was not related to residential satisfaction of the respondents.

The finding of ANOVA shows that there was significant differences in the overall residential satisfaction of the respondents among tenure status $(\mathrm{F}=4.498, \mathrm{df}=(2,361), p=0.012)$, house type $(\mathrm{F}=3.607, \mathrm{df}=(3,360), p$ $=.014)$ of the respondents. However, the ANOVA reveals that there was no significant difference in the overall residential satisfaction of the respondents based on their levels of education $(\mathrm{F}=.196, \mathrm{df}=(3,360), p=0.899)$, indicating that residential satisfaction of the respondents does not vary with level of education, those with lower level education may have similar overall level of satisfaction with those with higher level of education.

The finding of Independent t-tests shows also that there was no significant difference in the overall residential satisfaction among employment status $(\mathrm{t}=0.803$, $\mathrm{df}=362, p=0.063)$, indicating that being 
employed in public sector or private/self-employed does not make overall residential satisfaction to differ among the.

Table 2. Relationship between Background Characteristics and Overall Residential satisfaction

\begin{tabular}{|c|c|c|c|c|c|}
\hline Variables & $\mathbf{N}$ & Mean & SD & $\mathbf{r} / \mathbf{F} / \mathbf{t}$ & $P$ \\
\hline Age & 364 & 38.66 & 4.077 & $\mathrm{r}=0.209$ & 0.001 \\
\hline Household size & 364 & 6.25 & 1.648 & $\mathrm{r}=0.1639$ & 0.001 \\
\hline Household Monthly Income & 364 & 44306.46 & 36860.564 & $\mathrm{r}=0.2809$ & 0.001 \\
\hline Total number of bedrooms & 364 & 2.84 & 1.002 & $\mathrm{r}=0.3139$ & 0.001 \\
\hline Total number of rooms & 364 & 3.81 & 1.343 & $\mathrm{r}=0.3109$ & 0.001 \\
\hline Length of stay & 364 & 4.1 & .810 & $\mathrm{r}=-0.023$ & 0.450 \\
\hline Level of Education & & & & $F=0.196$ & 0.899 \\
\hline Not attended formal school & 64 & 3.59 & 0.328 & & \\
\hline Primary & 62 & 3.61 & 0.337 & & \\
\hline Secondary & 135 & 3.57 & 0.299 & & \\
\hline Tertiary & 103 & 3.58 & 0.269 & & \\
\hline \multicolumn{6}{|l|}{ Tenure status } \\
\hline Owner & 252 & 3.61 & 0.287 & $\mathrm{~F}=4.498$ & 0.012 \\
\hline Renter & 99 & 3.51 & 0.337 & & \\
\hline \multicolumn{6}{|l|}{ Rent Free } \\
\hline & 13 & 3.51 & 0.197 & & \\
\hline \multicolumn{6}{|l|}{ House type } \\
\hline Bungalow & 49 & 3.59 & 0.286 & $\mathrm{~F}=3.607$ & 0.014 \\
\hline Two-storey house & 8 & 3.67 & 0.376 & & \\
\hline Traditional Compound house & 98 & 3.5 & 0.334 & & \\
\hline Single family house(attached) & 209 & 3.62 & 0.281 & & \\
\hline Employment Sector & & & & $\mathrm{t}=0.803$ & 0.423 \\
\hline Public Employment & 191 & 3.56 & 0.283 & & \\
\hline Private/Self-Employed & 173 & 3.57 & 0.323 & & \\
\hline
\end{tabular}

Source: Authors' field work, 2013

Notes: $\mathbf{r}=$ Pearson's $r$ correlation coefficient, $\mathbf{F}=\mathrm{F}$ statistic for means comparison and $\mathbf{t}=\mathrm{t}$ statistics for comparison of means

\subsection{Discussion}

This study examined the relationship between backgroun characteristics (age, household size, household monthly income and length of stay) and residential satisfaction of young households in unplanned neighbourhoods. The significant positive relationship between age and residential satisfaction of the respondent is consistent with previous studies [5], [40], [41], [42] \& [43], but contrary to the finding of [44], [45] that age had negative correlation with residential satisfaction. This indicates that older among the young households are more satisfied than the younger as the former may have more for children and stayed in the residence before the later which may likely make them to have more friends and integrate well with the community. [37], argued that residential satisfaction relates positively with social integration. On the other hand, the significant positive and low correlation between household size and residential satisfaction of the respondents is contrary with the findings of previous studies [ 46], [4], [44] \& [47], while the finding is in line with studies by [48], [49] that found a positive correlation between larger household size and residential satisfaction. This indicates that the larger the size of the household the more the satisfaction, while the lower the household size, the lower the satisfaction. Moreover, the cultural tradition of many sub-Saharan African societies which values the contributions of children in farm works, domestic works, family businesses and family outputs is likely to have influence on their needs to get more children hence, large household size. In these societies, children provide a form of risk insurance in an uncertain environment and an investment in old-age security for their parents [50]. Therefore, families with more children might have high satisfaction than those few children and vice versa. 
With regard to positive correlation between household income and residential satisfaction, the finding is contrary with [51] that found negative correlation between household income level and residential satisfaction but consistent with [5], [52], [53] \& [24]. This indicates that young households with more income have higher satisfaction than those with lower level of income. This could be because those with high level of income have opportunities for homeownerships, housing repairs and for getting more housing facilities which are likely to raise their level residential satisfaction. However, those with low level income could not have these chances and as result, their level of satisfaction would become low. [54] found that higher income motivates move to better house in an attractive residential area, which may leads to relatively greater satisfaction level. Level of education had no significant relationship with residential satisfaction of young households in unplanned neighbourhood. This indicated that differences in level of education among young households could not their level of residential satisfaction differ. The finding shows that employment sector of the respondents had no significant relationship with their level of residential satisfaction, whether public sector employment or private/self-employed did not make level of satisfaction among young households differ. This is finding was contrary to previous studies [44], [53]. This could be because majority of the respondents were engaged in petty trading and other self-employment activities that may earned them much. Thus, similarity make makes the satisfaction not to differ among the respondents in unplanned neighbourhoods. However, tenure status and type of houses indicated positive significant correlation with residential satisfaction among the respondents. This suggested that owners among young households differed in terms of their satisfaction from renters and rent free which is in line with previous studies [5], [53].

Residential satisfaction of young households differed among type of houses with two storey houses having the highest satisfaction compared to renters and rent free .This finding is supported by [5], [53]. Residential satisfaction also differed among young households with those living in two storey houses and single family households having the highest satisfaction than those who were living bungalow and traditional compound houses. This finding is in line with previous studies that those living in single family houses were most satisfied [14]. On the total number of rooms and number of bedrooms which are proxy of housing space or dwelling size, the findings showed that they are positive and low correlation with residential satisfaction according to studies by [5], [55], [13] \& [44]. According to [25] housing space needs correlate positively with residential satisfaction. Similarly, [46] found in their study in public housing in Abuja, Nigeria that availability of space correlated positively with residential satisfaction, while [14] found that residential satisfaction differ with number of rooms and its size. However, the finding of the current study indicates that length of residence had no significant correlation between with residential satisfaction. This finding was consistent with the findings of [56]. It was contrary to the findings of [44], [23] \& [25] who found positive relationship between length of residence and residential satisfaction. The current finding indicates that the level of residential satisfaction of young households was not related to their length of residence. This could be because majority of them move to the neighbourhood almost the same time. Thus, their length of residence did not differ much.

\section{Conclusions}

In this study, Pearson's product moment correlation, ANOVA and independent t-tests were used to determine the relationship between background factors and residential satisfaction of the respondents. The findings revealed a positive relationship between age and residential satisfaction which implies that the higher the age of the respondents (older), the higher the residential satisfaction and even among the young households and that those with higher age are much most satisfied than those at lower age. Additionally, the finding also revealed significant positive and low relationship between household income and residential satisfaction which indicates, household income has impact on residential satisfaction of the respondents. This means that respondents with higher the income have the higher residential satisfaction. Similarly, the finding showed that the household size relate positively with residential satisfaction which indicates that respondents with large household size have showed higher level of residential satisfaction. However, no significant differences in residential satisfaction among employment sectors and also among level of educations of young households in the unplanned neighbourhoods. Total number of bedrooms and rooms also relate positively with young households' residential satisfaction. This suggested that young households with high number of rooms and bedroom indicated higher satisfaction with their residential environment than those with few numbers of rooms and bedrooms. This also suggests the need for more space among the respondents because of their household size. Finally, the length of stay of the respondents in the current neighbourhood was not related to residential satisfaction as shown in the study. Thus, this study proved that most background characteristics of the young households in unplanned neighbourhoods in Kano, Nigeria were related to their residential satisfaction. The study unveiled the need to consider the socio-economic status and their housing characteristics and conditions in any effort towards improving residential conditions and satisfaction of young households. The findings provide clear understanding 
of residential satisfaction theories that posited the influence of socioeconomic characteristics of the households on residential satisfaction.

\section{References}

[1] Muhammad, M. \& Bichi, A. M. (2014). Constraints and challenges on housing provision in Kano city, Nigeria. International Journal of Advancements in Research \& Technology, 3 (6), 4 - 23.

[2] Jiboye and Omoniyi (2013) Evaluation of residents' housing and neighbourhood preferences in Nigeria: Providing feedback for public housing delivery. International Journal of of Arts \& Sciences, 6(2);, $221-240$.

[3] Potter, J., Chocoine, L., Speicher, K. (2001). Predicting residential satisfaction: A comparative case of study. Architectural programs at digital commons university of Nebrasca - Lincoln.

[4] Jiboye, A. D. (2009). Evaluating Tenants' Satisfaction with Public Housing in Lagos, Nigeria. Town Planning and Architecture, 33(4), 239-247.

[5] Lu, M. (1999). Determinants of residential satisfaction: ordered logit vs. regression models. Growth and Change, 30(2), $264-287$.

[6] Dunstan, F., Weaver, N., Araya, R., Bell, T., Lannon, S., Lewis, G., . . Palmer, S. (2005). An observation tool to assist with the assessment of urban residential environments. Journal of Environmental Psychology, 25(3), 293-305.

[7] Jiboye, A. D. (2010). The correlates of public housing satisfaction in Lagos, Nigeria. Journal of geography and regional planning, $3(2), 017-028$.

[8] Makinde, O. O. Influences of socio-cultural experiences on residents' satisfaction in Ikorodu low-cost housing estate, Lagos state. Environment, Development and Sustainability, 1-26.

[9] Waziri, A. G., Yusof, N., \& Salleh, A. G. (2013). Residential Satisfaction with Private Housing Estate Development in AbujaNigeria. ALAM CIPTA, International Journal of Sustainable Tropical Design Research and Practice, 6(2), 3-12.

[10] Galster, G. C., \& Hesser, G. W. (1981). Residential Satisfaction. Environment and Behavior, 13(6), $735-758$.

[11] Galster, G. (1987). Identifying the correlates of dwelling satisfaction. Environment and Behavior, 19(5), 539-568.

[12] Amérigo, M. A., \& Aragones, J. I. (1997). A theoretical and methodological approach to the study of residential satisfaction. Journal of Environmental Psychology, 17(1), 47-57.

[13] Vera-Toscano, E., \& Ateca-Amestoy, V. (2008). The relevance of social interactions on housing satisfaction. Social Indicators Research, 86(2), 257-274.

[14] Jansen, S. (2014). The impact of the have-want discrepancy on residential satisfaction. Journal of Environmental Psychology.

[15] Amole, D. (2009). Residential satisfaction in students' housing. Journal of Environmental Psychology, 29(1), 76-85.

[16] Bonaiuto, M., Bonnes, M., \& Continisio, M. (2004). Neighborhood evaluation within a multiplace perspective on urban activities. Environment and Behavior, 36(1), 41-69.

[17] Francescato, G. (2002). Residential satisfaction research: the case for and against. In Residential environments: Choice, satisfaction, and behaviour (pp. 15-34).

[18] Speare, A. (1974). Residential satisfaction as an intervening variable in residential mobility. Demography, 11(2), 173-188.

[19] Bonaiuto, M., Fornara, F., \& Bonnes, M. (2006). Perceived residential environment quality in middle-and low-extension Italian cities. Revue Européenne de Psychologie Appliquée/European Review of Applied Psychology, 56(1), 23-34.

[20] Morris, E. W., \& Winter, M. (1975). A theory of family housing adjustment. Journal of Marriage and the Family, 79-88.

[21] Morris, E. W., \& Winter, M. (1978). Housing, family, and society: John Wiley and Sons.

[22] Mohit, M. A., \& Nazyddah, N. (2011). Social housing programme of Selangor Zakat Board of Malaysia and housing satisfaction. Journal of Housing and the Built Environment, 26(2), 143-164.

[23] Zanuzdana, A., Khan, M., \& Kraemer, A. (2013). Housing satisfaction related to health and importance of services in urban slums: evidence from Dhaka, Bangladesh. Social indicators research, 112(1), 163-185.

[24] Ibem, E. O., \& Aduwo, E. B. (2013). Assessment of residential satisfaction in public housing in Ogun State, Nigeria. Habitat International, 40, 163-175.

[25] Li, Z., \& Wu, F. (2013). Residential Satisfaction in China's Informal Settlements: A Case Study of Beijing, Shanghai, and Guangzhou. Urban Geography, 34(7), 923-949.

[26] Mudege, N. N., \& Zulu, E. M. (2011). In their own words: Assessment of satisfaction with residential location among migrants in Nairobi slums. Journal of Urban Health, 88(2), 219-234.

[27] Clark, W. A., \& Onaka, J. L. (1983). Life cycle and housing adjustment as explanations of residential mobility. Urban Studies, 20(1), 47-57.

[28] Bashir, A. (2003). Regional Planning and Urban Infrastructure Development in the Gongola Region, North Eastern, Nigeria, Global Journal of Social Sciences, 2(1), $75-82$.

[29] Lusugga Kironde, J. M. (2006). The regulatory framework, unplanned development and urban poverty: Findings from Dar es Salaam, Tanzania. Land Use Policy, 23(4), 460-472.

[30] Khalifa, M. A. (2011). Redefining slums in Egypt: Unplanned versus unsafe areas. Habitat International, $35(1), 40-49$.

[31] Dankani, I. M. (2013). Constraints to sustainable physical planning in metropolitan Kano, International Journal of Management and Social Sciences Research, 2( 3), $34-42$.

[32] Mustapha, A., Abdu, A., \& Geidam, A. L. (2013). The Influence of landuse and land-cover changes on surface water quality variations in the Jakara basin North- Western Nigeria. International Journal of Advanced and Innovation Research \& Technology, 2(3) $158-164$.

[33] Nabegu, A. B. (2010). An analysis of municipal solid waste in Kano Metropolis, Nigeria. Journal of Human Ecology, 31(2), 111119

[34] National Population Commission (NPC), (2009). 2006 Population and Housing Census of the Federal Republic of Nigeria Priority Tables (Volume I): National and State Population and Housing Tables. Abuja, Nigeria. Retrieved 29/05/201 http://www.population.gov.ng/index.php/publications/136-housing-characteristics-and- ameniti.. 130 - 222.

[35] Home, R. K. (1986). Urban development boards in Nigeria: the case of Kano. Cities, 3(3), 228-236.

[36] Krejcie, R. V., \& Morgan, D. W. (1970). Determining sample size for research activities. Educ Psychol Meas.

[37] Hashim, A. H. (2003). Residential satisfaction and social integration in public low cost housing in Malaysia. Pertanika Journal of Social Sciences \& Humanities, 11(1), 1-10.

[38] Pallant, J. (2011). SPSS Survival Manual 4th edition: A step by step guide to data analysis using SPSS version 18: Maidenhead, Berkshire: Open University Press. Retrieved on 10/05/2012 from http://www. allenandunwin. com/spss.

[39] Field, A. (2013). Discovering statistics using IBM SPSS statistics: Sage publications, London. 
[40] Oswald, F., Wahl, H.-W., Mollenkopf, H., \& Schilling, O. (2003). Housing and life satisfaction of older adults in two rural regions in Germany. Research on aging, 25(2), 122-143.

[41] Pinquart, M., \& Burmedi, D. (2003). Correlates of residential satisfaction in adulthood and old age: A meta-analysis. Annual review of gerontology and geriatrics, 23, 195-222.

[42] Chapman, D. W., \& Lombard, J. R. (2006). Determinants of neighborhood satisfaction in fee-based gated and nongated communities. Urban Affairs Review, 41(6), 769-799.

[43] Baum, S., Arthurson, K., \& Rickson, K. (2010). Happy people in mixed-up places: the association between the degree and type of local socioeconomic mix and expressions of neighbourhood satisfaction. Urban Studies, 47(3), 467-485.

[44] Mohit, M. A., Ibrahim, M., \& Rashid, Y. R. (2010). Assessment of residential satisfaction in newly designed public low-cost housing in Kuala Lumpur, Malaysia. Habitat International, 34(1), 18-27.

[45] Mohit, M. A., \& Azim, M. (2012). Assessment of Residential Satisfaction with Public Housing in Hulhumale', Maldives. ProcediaSocial and Behavioral Sciences, 50, 756-770.

[46] Ukoha, O. M., \& Beamish, J. O. (1996). Predictors of housing satisfaction in Abuja, Nigeria. Housing and Society, 23(3), $26-46$.

[47] Tan, T.-H. (2011). Determinants of housing satisfaction in Klang Valley, Malaysia.

[48] Cook, C. C. (1988). Components of neighborhood satisfaction responses from urban and suburban single-parent women. Environment and Behavior, 20(2), 115-149.

[49] Adams, R. E. (1992). Is happiness a home in the suburbs?: The influence of urban versus suburban neighborhoods on psychological health. Journal of Community Psychology, 20(4), 353-372.

[50] Okezie, C., Ogbe, A., \& Okezie, C. (2010). Socio-economic determinants of contraceptive use among rural women in Ikwuano Local Government Area of Abia State, Nigeria. Int NGOJ, 5(4), 74-77.

[51] Teck-Hong, T. (2012). Housing satisfaction in medium-and high-cost housing: The case of Greater Kuala Lumpur, Malaysia. Habitat International, 36(1), 108-116.

[52] Adriaanse, C. C. M. (2007). Measuring residential satisfaction: a residential environmental satisfaction scale (RESS). Journal of housing and the built environment, 22(3), 287-304.

[53] Lovejoy, K., Handy, S., \& Mokhtarian, P. (2010). Neighborhood satisfaction in suburban versus traditional environments: An evaluation of contributing characteristics in eight California neighborhoods. Landscape and Urban Planning, 97(1), 37-48.

[54] Frank, B., \& Enkawa, T. (2009). Economic drivers of dwelling satisfaction: Evidence from Germany. International Journal of Housing Markets and Analysis, 2(1), 6-20.

[55] Elsinga, M., \& Hoekstra, J. (2005). Homeownership and housing satisfaction. Journal of housing and the built environment, 20(4), 401-hoeween 424.

[56] Onibokun A. G. (1974). Evaluation of consumer satisfaction with housing. An application of a social system approarch. Journal of American Institute of planners 40(May), 189- 200. 